\title{
Guidelines In the Work of Operating Room Nurses
}

1 Marin Repustić

1 General Hospital "dr. Ivo Pedišić", Sisak, Croatia

Article received: 02.11.2021.

Article accepted: 06.12.2021.

Author for correspondence:

Marin Repustić

Department for Ensuring and Improving the Quality of

Healthcare

General Hospital "dr. Ivo Pedišić"

Josipa Jurja Strossmayera 59, 44000 Sisak, Croatia

E-mail: marin.repustic@gmail.com

https://doi.org/10.24141/2/5/2/7

Keywords: guidelines, operating room nurses, patient safety

\section{Abstract}

Introduction. The use of guidelines in the work of operating room nurses makes daily tasks easier and enables treatment in accordance with set procedures based on scientific evidence. Additionally, the use of set guidelines in the work of operating room nurses enables traceability of healthcare and the best care for the patient, which also increases the safety of the patient in the operating room during the perioperative period.

Aim. The goal of this article is to investigate and determine if operating room nurses are aware of the guidelines, if they use them in their daily work, and if the guidelines are available at their workplace. The goal is also to determine the opinion of operating room nurses about legal protection that the guidelines provide in case of unforeseen events, as well as the necessary level of education of the personnel setting the guidelines, and the effect of the guidelines on the patient's safety in the operating room. Additionally, it is to determine if the use of the guidelines reduces inconsistencies in the work of operating room nurses in different hospitals, and which institutions are in charge of setting them.

Methods. The survey for this research was conducted by the author of this paper and was distributed at the Congress of Operating Room Nurses in October of 2019. 210 operating room nurses completed the survey, being of different levels of formal education, and are employees of various Clinical Hospital Cen- 
tres, Clinical Hospitals and General Hospitals in the Republic of Croatia.

Results. According to the results of the survey, 90 respondents were Bachelors of Nursing, 60 respondents had a university degree, and 60 respondents had a high school diploma. The length of work experience of the operating room nurses who participated in the survey was between 1 and 30 years. The results of the research showed that the majority of operating room nurses were familiar with the existence of the guidelines and recommendations, and they used them in their work. Results show that most respondents are aware of the need to use the guidelines, and that they are available at their work place. Results also show that operating room nurses feel that the use of the guidelines has a very strong influence on the level of patient safety. Operating room nurses know that the guidelines provide legal protection and that the level of the nurses' education is important for setting the guidelines.

Conclusion. Operating room nurses use the guidelines in daily work whenever they are applicable. Respondents have also developed an awareness of the obligation to use the guidelines, as well as their benefits in improving patient safety. They also provide legal protection in the event of unforeseen circumstances.

\section{Introduction}

Using clinical guidelines, doctors, nurses and other healthcare staff have clearly defined algorithms to follow, which greatly eases the work of healthcare workers and can enable, to an extent, legal protection in case of an unforeseen event during treatment. Clinical guidelines are not all-encompassing and it is not possible to use them in every situation. During treatment, the complexities of each individual case have to be taken into account, and the guidelines sometimes cannot be followed due to a lack of staff, materials or other resources. Considering nursing as a science - as opposed to healthcare as a specific area of a nurse's work - demands a level of expertise based on evidence. Unlike in other scientific disciplines, in the field of nursing, historically, the distinctive patient-nurse relationship is a very specific phenomenon (1). In view of the legal obligation of documenting nursing work and the development of tracking care indicators, as well as analyzing patient safety indicators and the quality of healthcare (including the outcome of patient care), nurses have to be able to demonstrate measurable outcomes and work on constantly improving them (2).

The guidelines are systematically developed statements which help users make decisions on appropriate healthcare for the patient in certain clinical circumstances (3).

Work guidelines are made by professional boards, using the latest knowledge and nursing, based on evidence. Additionally, the guidelines must contain the best and strongest available evidence on which we base our decisions in patient care.

EORNA - The European Operating Room Nurses Association, recognized the importance of the guidelines and has created operating room recommendations in a way to ensure the highest possible level of safety and quality of healthcare during operating procedures. The recommendations and guidelines issued by EORNA are based on empirical evidence during perioperative care. EORNA sets the guidelines in the following areas: perioperative healthcare, patient and staff safety, hygiene and sanitation in the operating room, and work guidelines during pandemics. The main idea in setting and using the guidelines for operating nurses, according to EORNA, is the need to implement standard operating procedures that are made by national and international bodies approved by European regulatory institutions. Also, one of the main goals of the guidelines is to give evidencebased answers to matters of perioperative care, so that the best decision can be applied in practice. It is necessary to keep in mind that the guidelines are not and cannot be all-encompassing, which means that they cannot cover every individual case, particularity of the operating room, surgical procedure or available instruments. The process of developing the guidelines is long and demands a multidisciplinary and exact methodological approach, grading evidence and good technical support. While setting the guidelines, there is a focus on the methodological process of systematically consulting literature and seeking evidence, but the quality of the guidelines also depends on the social process, affected by the equality of all members of the workgroup in constructively discussing and applying the evidence. The cohesion and di- 
versity of the team are important, as small teams are inexperienced but large teams are hard to manage. It is considered that the optimal team consists of 8 to 10 members, but larger groups can also work in a satisfactory manner (4).

The guidelines state that a team constitutes a certain number of members who must in no way be in a conflict of interest and there should not be any other factors that could influence making decisions and defining the guidelines. Because of this, members of the team are obligated to state any possibility of a conflict of interest. The guidelines must be of a suitable quality, purposeful and all-encompassing. The attributes of good guidelines are that they are based on evidence and set by multidisciplinary and independent teams. When following the guidelines, it is mandatory to grade the importance of the recommendations used in making the guidelines. It is also necessary to revise the guidelines if there is new evidence or a change in the level of importance of the recommendation. Before publishing the guidelines, it is necessary to carry out quality control, as the quality of the guidelines is one of the main conditions for its use and assistance in everyday work. The Appraisal of Guidelines for Research \& Evaluation Instrument (AGREE II) is used for grading the quality of the guidelines. The tool was developed in 2009 and updated in 2013. It consists of 23 items, and the aspects that are graded are scope and purpose, stakeholder involvement, rigour of development, clarity of presentation, applicability, and editorial independence. It is also recommended that the assessment according to AGREE II is made by two independent appraisers. The Registered Nurses Association of Ontario has set the basic framework for the content of the guidelines, both nursing and clinical. The framework consists of a cover, details of the organization issuing the guidelines, content, and the basic data of the process in defining the guidelines (introduction, field, summary of recommendations, interpretation of evidence, list of team members, list of external editors and stakeholders, context in the development of the guidelines, recommendations, implementation strategy, renewing guidelines, acknowledgments, conflict of interest statement, literature and appendices) (5). In addition to the above, it is clear that the process of developing guidelines is extremely comprehensive and complex, and demands a significant amount of resources. There are not a lot of guidelines in nursing in the Republic of Croatia, but the work of nurses is defined through the standard process of healthcare and the standards of operating rooms. Taking into account the claim that the unique role of nurses is defined in the theory of healthcare (the basis of nursing as a science), which means that nursing is not merely a part of another profession, but that it consists of theory, practice and research (6). Nursing work must be in accordance with the latest scientific knowledge, which is provided by the guidelines. In the rigorous environment of the operating room, the standards are not sufficient for quality work that would provide the highest possible level of safety for the patient and staff. Because of this, operating room nurses use the available recommendations and guidelines. Additionally, the guidelines are necessary to manage, categorize and revise risks in the operating room. If there are no adequate guidelines, it is impossible to manage the risks in each and every work place. The ISO 31000:2018 guidelines consist of risk management awareness, and this document can be adapted to any organization. It does not apply to any specific sector or industry, and is applicable to any life situation or work process.

\section{Aim}

The aim is to determine:

1. Years of work experience of the survey respondents.

2. Level of education of operating room nurses (respondents).

3. Whether operating nurses are aware of the guidelines.

4. Whether operating room nurses come into contact with the guidelines.

5. How often operating room nurses use the guidelines.

6. If the guidelines affect the safety of patients and staff.

7. If the use of guidelines provides legal protection.

8. If the use of guidelines decreases inconsistencies between health institutions.

9. Which institutions participate in developing the guidelines. 


\section{Hypothesis}

$\mathrm{H} 1$ : operating room nurses use guidelines in their everyday work if they are applicable.

$\mathrm{H} 2$ : the guidelines affect the safety of patients in the operating room.

H3: the use of guidelines decreases inconsistencies between health institutions.

\section{Methods}

The research included 210 operating room nurses who completed the survey. Their work experience is between 1 and 30 years. The questionnaire for this research was designed in Microsoft Word, it was created for the purpose of this research, and completed by the respondents in person. The anonymity of the respondents is guaranteed by not asking for their identification or health institution they work at. There were three possible answers to the questions - 1. Agree, 2. Partly agree, and 3. Disagree.

The questions were comprised of the following: job description, years of experience in the operating room, category of their institution, level of education, awareness of the guidelines, contact with the guidelines, opinion of the guidelines, awareness of the process of developing the guidelines, use of the guidelines in their everyday work, their perception of the importance of using the guidelines, the influence of education level in setting the guidelines, awareness of institutions that set the guidelines, the influence that implementing the guidelines has on patient safety and work quality in the operating room, awareness of legal protection the guidelines offer, whether the guidelines reduce variability in the work of operating room nurses, what the foundations of the guidelines are, priorities in setting the guidelines, and willingness to participate in defining the guidelines. The research was conducted in October of 2019. The data was entered and processed in an Excel table.

\section{Results}

Table 1. Work experience of respondents

\begin{tabular}{|c|c|c|}
\hline $\begin{array}{c}\text { Work } \\
\text { experience in } \\
\text { operating room }\end{array}$ & $\begin{array}{c}\text { Number of } \\
\text { respondents }\end{array}$ & Percentage (\%) \\
\hline $1-5$ & 20 & 9.5 \\
\hline $5-10$ & 20 & 9.5 \\
\hline $10-15$ & 30 & 14.2 \\
\hline $15-20$ & 35 & 16.6 \\
\hline $20-25$ & 50 & 23.8 \\
\hline $25-30$ & 35 & 16.6 \\
\hline 30 and more & 20 & 9.5 \\
\hline
\end{tabular}

The survey was completed by 210 respondents, of which the highest number of nurses has operating room work experience of between 20 and 25 years (23.8\%). The percentage of respondents with 25 to 30 years of operating room work experience is $16.6 \%$.

Table 2. Education level of respondents

\begin{tabular}{|c|c|c|}
\hline Education level & $\begin{array}{c}\text { Number of } \\
\text { respondents }\end{array}$ & Percentage (\%) \\
\hline High school & 60 & 28.5 \\
\hline Bachelor & 90 & 42.8 \\
\hline Master & 60 & 28.5 \\
\hline
\end{tabular}

$42.8 \%$ of respondents are Bachelors of Nursing, while the same percentage (28.5\%) of respondents have a high school or Master's degree. The data confirms that the respondents have a high level of formal education and most of them understand and are aware of the guidelines. 
Table 3. Awareness of the existence of guidelines

\begin{tabular}{|c|c|c|}
\hline $\begin{array}{c}\text { Awareness of } \\
\text { guidelines }\end{array}$ & $\begin{array}{c}\text { Number of } \\
\text { respondents }\end{array}$ & Percentage (\%) \\
\hline Aware & 136 & 64.7 \\
\hline Not aware & 74 & 35.2 \\
\hline
\end{tabular}

$64.7 \%$ of respondents are aware of the existence of the guidelines. This is a relatively low percentage and this is why there is a need for additional distribution of information about the existence of the guidelines.

Table 4. Contact with guidelines in everyday work

\begin{tabular}{|c|c|c|}
\hline $\begin{array}{c}\text { Contact with } \\
\text { guidelines }\end{array}$ & $\begin{array}{c}\text { Number of } \\
\text { respondents }\end{array}$ & Percentage (\%) \\
\hline Has contact & 115 & 54.7 \\
\hline $\begin{array}{c}\text { Has partial } \\
\text { contact }\end{array}$ & 48 & 22.8 \\
\hline Has no contact & 47 & 22.3 \\
\hline
\end{tabular}

More than half of the respondents (54.7\%) have contact with the guidelines in their everyday work.

Table 5. The use of guidelines in everyday work

\begin{tabular}{|c|c|c|}
\hline $\begin{array}{c}\text { Use of } \\
\text { guidelines }\end{array}$ & $\begin{array}{c}\text { Number of } \\
\text { respondents }\end{array}$ & Percentage (\%) \\
\hline Regularly & 136 & 64.7 \\
\hline Sometimes & 0 & 0 \\
\hline Never & 74 & 35.2 \\
\hline
\end{tabular}

$64.7 \%$ of respondents use the guidelines in their everyday work, which signals the need for additional information and education about the use of the guidelines and their availability to operating room nurses.
Table 6. Influence of guidelines on patient safety

\begin{tabular}{|c|c|c|}
\hline $\begin{array}{c}\text { Influence on } \\
\text { patient safety }\end{array}$ & $\begin{array}{c}\text { Number of } \\
\text { respondents }\end{array}$ & Percentage (\%) \\
\hline Strong & 184 & 87.6 \\
\hline Partial & 21 & 10 \\
\hline None & 5 & 2.3 \\
\hline
\end{tabular}

The majority of respondents (87.6\%) consider the guidelines to have a strong influence on patient safety in the operating room, which supports the use of the guidelines in everyday work.

\section{Table 7. Legal coverage with the use of guidelines in everyday work}

\begin{tabular}{|c|c|c|}
\hline $\begin{array}{c}\text { Legal coverage } \\
\text { with the use of } \\
\text { guidelines }\end{array}$ & $\begin{array}{c}\text { Number of } \\
\text { respondents }\end{array}$ & Percentage (\%) \\
\hline Agree & 154 & 73.3 \\
\hline Partly agree & 48 & 22.8 \\
\hline Disagree & 8 & 3.8 \\
\hline
\end{tabular}

$73.3 \%$ of respondents agree with the statement that using the guidelines in the operating room allows for legal protection in the case of an unforeseen event.

Table 8. Inconsistencies in work among health institutions

\begin{tabular}{|c|c|c|}
\hline $\begin{array}{c}\text { Reduced } \\
\text { variability in } \\
\text { work }\end{array}$ & $\begin{array}{c}\text { Number of } \\
\text { respondents }\end{array}$ & Percentage (\%) \\
\hline Agree & 168 & 80 \\
\hline Partly agree & 41 & 19.5 \\
\hline Disagree & 9 & 4.2 \\
\hline
\end{tabular}

$80 \%$ of respondents agree that using the guidelines reduces inconsistencies in the work of various health institutions. 


\section{Table 9. Institutions which participate in developing guidelines}

\begin{tabular}{|c|c|c|}
\hline $\begin{array}{c}\text { Institutions } \\
\text { which } \\
\text { participate in } \\
\text { developing } \\
\text { guidelines }\end{array}$ & $\begin{array}{c}\text { Number of } \\
\text { respondents }\end{array}$ & Percentage (\%) \\
\hline $\begin{array}{c}\text { Expert operating } \\
\text { room nurses }\end{array}$ & 112 & 53.3 \\
\hline $\begin{array}{c}\text { Croatian } \\
\text { operating } \\
\text { room nurses } \\
\text { association }\end{array}$ & 80 & 38 \\
\hline $\begin{array}{c}\text { Croatian nursing } \\
\text { council }\end{array}$ & 18 & 8.5 \\
\hline
\end{tabular}

A total of $91.3 \%$ of respondents claim that the guidelines must be developed by experts, operating room nurses and the Croatian Operating Room Nurses Association.

\section{Discussion}

210 operating room nurses participated in the research, of which $66.5 \%$ had more than 15 years of work experience in operating rooms. $71.3 \%$ of respondents are operating room nurses with a Bachelor's or Master's degree, which gives us a great insight into the educational structure of operating room nurses, and that is one of the main conditions for recognizing the guidelines and their everyday use. $64.7 \%$ of respondents regularly use all the guidelines in the operating room, which confirms Hypothesis 1. $35.2 \%$ of respondents do not use the guidelines in their everyday work, which necessitates additional education of staff concerning the existence and benefits of regularly using the guidelines. The responses of $87.6 \%$ of participants prove Hypothesis 2 , which refers to increasing the level of patient and staff safety in the operating room. This is due to the fact that the guidelines always provide data about the latest approach in patient care based on scientific evidence and is proven by independent experts, greatly ensuring that the guidelines are a safety tool as well. $80 \%$ of respondents confirmed that the use of guidelines reduces inconsistencies in the work of operating room nurses in certain health institutions, which is a basic requirement for quality healthcare for all patients, confirming Hypothesis 3. The use of the guidelines reduces inconsistencies in work, as they have been devised by experts in specific fields, based on specific studies, multiple studies of the same type or with the same analytical goal. Prior to publication, they are regularly revised in accordance with the latest research, as well as quality checked and edited to be clear and applicable. Taking into consideration that $54.7 \%$ of operating room nurses use the guidelines in their everyday work in the operating room, it is clear that half of the respondents have an insight into the latest scientific approach concerning the patient during perioperative care.

The use of the guidelines greatly eases work in the operating room, where new technologies are implemented on a daily basis. This includes ultrasonic knives, electrosurgical platforms, gamma knives, as well as the latest surgical procedures. Frequently introducing the latest technologies and procedures into the operating room environment can often lead to mistakes, in spite of education. Mistakes can be made while using technology on a patient in regular perioperative healthcare procedures, and in that case, the guidelines can somewhat provide legal protection. More than two-thirds of respondents agree with this claim.

Almost all respondents (91.3\%) feel that the guidelines for operating room nurses must be devised by expert operating room nurses and the Croatian Operating Room Nurses Association.

Moreover, it is obvious that nursing has to be closely tied to guideline development because it provides a scientific approach to the profession and ensures accessible information about existing options in quality patient care.

Other research on this topic does not provide a significant amount of data. In the conclusion of "Good Practices for Patient Safety in the Operating Room: Nurses' Recommendations", Louisa de Siquiera Gutieres, et all. (2018), it was stated that the use of guidelines in the operating room is one of the basic tools that operating room nurses use and they are a necessity in the strategy development for patient care in the operating room (7), which affirms the results of this research paper.

In the prologue of their guidelines and recommenda- 
tions issues, The Association of periOperative Registered Nurses (AORN) and The European Operating Room Nurses Association (EORNA) also state that the use of guidelines is one of the primary advantages within healthcare, especially in the operating room (8).

\section{Conclusion}

The use of guidelines in the work of nurses and operating room nurses is imperative for all healthcare institutions, as it provides significant benefits.

In the research results, and through discussion, it is evident that operating room nurses are aware of guidelines for their work, and a significant number use them. The majority of respondents perceive the guidelines to be necessary. The research also shows that the guidelines are available at their workplaces. According to the results of the research, it is also clear that operating room nurses believe the guidelines offer sufficient legal protection in the case of unforeseen events. They also consider them to have a significant impact on increasing patient safety during perioperative care, as well as increasing the level of work quality in the operating room. The majority of respondents agree with the statement that the work guidelines need to be devised by expert associations. They also agree that the use of guidelines in everyday work enables the reduction of inconsistencies, as the same approach, method and procedures are used in their application in all workplaces.

We must take into account the fact that the guidelines are systematic insights into scientific truths, and have the primary goal of educating healthcare workers. Their end goal is to improve decision-making, consequently improving the outcomes of healthcare procedures.
The guidelines cannot always cover every single aspect of the patient, the operating room and available technology (highly sophisticated equipment that is regularly used during surgery). Sometimes we are unable to apply them, so the final decision on using the guidelines lies on the healthcare worker, although it is highly recommended they are followed in every possible situation.

\section{References}

1. Kalauz S. Sestrinstvo-znanost ili vještina/tehne. U: Kalauz S. Etika u sestrinstvu. Zagreb: Medicinska naklada; 2012. Croatian.

2. Lehrman E. Using Nursing Research in Practice. In: Zerwek J, Claborn, JC. Nursing Today: Transition and Trends. St. Louis, Missouri: Elsevier; 2003.

3. Harbour R, Lowe G, Twaddle S. Scottish Intercollegiate Guidelines Network: The First 15 Years (1993-2008). J R Coll Physicians Edinb. 2011;41(2):163-8.

4. Eccles MP, Grimshaw JM, Shekelle $P$, Schünemann $H$, Woolf S. Developing Clinical Practice Guidelines: target audiences, identifying topics for guidelines, guideline group composition and functioning, and conflicts of interest. Implement Sci. 2012;7:60.

5. About Healthy Work Environments BPGs. Registered Nurses' Association of Ontario. Available at: https:// rnao.ca/bpg/guidelines/hwe Accessed: 30.09.2018.

6. Joel A. Nursing as a Profession. In: Joel A. Kelly's Dimension of Professional Nursing. New York: McGraw Hill Professional; 2003.

7. Gutierres LS, Santos JLGD, Peiter CC, Menegon FHA, Sebold LF, Erdmann AL. Good Practices for Patient Safety in the Operating Room: Nurses' Recommendations. Rev Bras Enferm. 2018;71(suppl 6):2775-82.

8. EORNA Best Practice for Perioperative Care. Brussels, Belgium: The European Operating Room Nurses Association (EORNA), 2020. 


\section{SMJERNICE U RADU OPERACIJSKIH SESTARA INSTRUMENTARKI}

\section{Sažetak}

Uvod. Primjena smjernica u radu operacijskih sestara instrumentarki uvelike olakšava njihov svakodnevni rad i omogućuje postupanje u skladu s propisanim procedurama koje su zasnovane na znanstvenim dokazima. Također, primjena smjernica u svakodnevnom radu operacijskih sestara instrumentarki omogućuje je sljedivost zdravstvenog postupka i najbolju moguću skrb za bolesnika, što ujedno povisuje razinu sigurnosti bolesnika u operacijskoj sali tijekom perioperacijskog perioda.

Cilj. Cilj je ovog rada istražiti i utvrditi imaju li operacijske sestre informacije o postojanju smjernica, primjenjuju li operacijske sestre instrumentarke smjernice u svojem svakodnevnom radu i jesu li im smjernice dostupne na radnim mjestima. Također, cilj je rada utvrditi stav operacijskih sestara instrumentarki o pravnoj zaštiti koju omogućuje primjena smjernica u slučaju nastanka neželjenog događaja, potrebnoj razni edukacije osoba koje sudjeluju u izradi smjernica, utjecaju primjene smjernica na razinu sigurnosti bolesnika u operacijskoj sali, utvrditi smanjuje li primjena smjernica varijabilnosti u radu operacijskih sestara instrumentarki između pojedinih zdravstvenih ustanova te koje su institucije nadležne za izradu smjernica.

Metode. Upitnik za potrebe ovog istraživanja izradio je autor rada i distribuiran je na Stručnom skupu operacijskih sestara koji je održan u listopadu 2019. $\mathrm{U}$ ispunjavanju anketnog upitnika sudjelovalo je 210 operacijskih sestara i tehničara instrumentara, koji su različitih razina formalne edukacije i zaposlenici su kliničkih bolničkih centara te kliničkih i općih bolnica u Republici Hrvatskoj.

Rezultati. Prema rezultatima anketnog upitnika, ispitanici su najvećim dijelom prvostupnici sestrinstva, ukupno 90 ispitanika, 60 ispitanika medicinske su sestre i tehničari visoke stručne spreme, 60 ispitanika medicinske su sestre i tehničari srednje stručne spreme. Broj godina rada ispitanika u operacijskim salama kreće se od jedne do 30 i više godina. Rezultati istraživanja pokazali su da je najveći dio operacijskih sestara instrumentarki upoznat $s$ postojanjem smjernica i preporuka za rad te ih primjenjuju u svojem svakodnevnom radu. Također, rezultati pokazuju da je kod najvećeg dijela ispitanika razvijena spoznaja o obvezi primjene smjernica za rad i da su smjernice za rad dostupne na radnim mjestima. Rezultati pokazuju kako operacijske sestre i tehničari smatraju da upotreba smjernica ima snažan utjecaj na razinu sigurnosti bolesnika, kao i da smjernice omogućuju pravnu zaštitu i da je za izradu smjernica važna razina edukacije medicinskih sestara.

Zaključak. Zaključak je da operacijske sestre instrumentarke redovno primjenjuju smjernice kad su im god dostupne. Također kod ispitanika je razvijena svijest o obvezi primjene smjernica i njihovim koristima u unaprjeđenju sigurnosti bolesnika, kao i o tome da smjernice omogućuju pravnu zaštitu u slučaju neželjenog događaja.

Ključne riječi: smjernice, operacijska sestra instrumentarka, sigurnost pacijenta 